as high a concentration as this spontaneously. Nevertheless, there was no indication of increased aggression, though she was very dramatically virilised.

A wide range of ovarian tumours can secrete androgens. ${ }^{1}$ Though virilisation is often severe, serum testosterone concentrations are usually increased only up to the normal male range at the most. After resection of the tumour she showed a dramatic response that greatly exceeded everyone's expectations.

The diagnosis was delayed principally because the wrong test was carried out. This case shows that measurements of serum testosterone and androstenedione concentrations, perhaps with dehydroepiandrosterone sulphate, are very much better at excluding virilising tumours than urinary 17 ketosteroid excretion, which correlates poorly with serum androgen concentrations. ${ }^{2}$ Ketosteroid excretion generally represents the weaker adrenal androgens, ${ }^{3}$ and though her testosterone concentration 11 years previously was probably much lower than it was at the time of diagnosis it would doubtless already have been considerably increased at that time.

1 Ireland K, Woodruff JD. Masculinising ovarian tumours. Obstet Gynecol Surv 1976;31:83-111.

2 Farber M, Millan VG, Turksoy RN, Mitchell JR. Diagnostic evaluation of hirsutism in woman by selective bilateral adrenal and ovarian venous catheterisation. Fertil Steril 1978;30:283-8.

3 Judd HL, McPherson RA, Rakoff JS, Yes SSC. Correlation of the effects of dexamethasone administration on urinary 17 ketosteroid and serum androgen levels in patients with hirsutism. Am F Obstet Gynecol 1977;128:408.

(Accepted 9 October 1986)

Departments of Medicine and Dermatology, University of Manchester

H M BUCKLER, BMEDSCI, MRCP, tutor in medicine

D M MITCHELL, MB, MRCP, registrar in dermatology

$M$ H BECK, MB, MRCP, consultant dermatologist

DC ANDERSON, MD, FRCP, professor of endocrinology

Correspondence to: Professor D C Anderson, Department of Medicine, Clinical Sciences Building, Hope Hospital, Salford M6 8HD.

\section{Fall and rise of immunity to rubella}

We report a study of the prevalence of rubella antibody in a sample of children and adolescents who attended the children's department at Leeds General Infirmary. The purposes of this study were to determine whether the age at which antibody is acquired had changed since the introduction of rubella vaccination in 1970 and to use the results as an aid in interpreting the importance of rubella antibody in young children suspected of having congenital rubella.

\section{Patients, methods, and results}

Blood was obtained from 245 children and adolescents who underwent venepuncture in the course of other investigations while attending the hospital between October 1985 and July 1986. All serum samples were tested for rubella antibodies by single radial haemolysis and haemagglutination inhibition tests using standard methods. ${ }^{1}$ In the microtitre haemagglutination inhibition test pigeon erythrocytes were used to indicate haemagglutination, and all serum samples were pretreated with kaolin. In all cases the presence or absence of antibody was confirmed by both the haemagglutination inhibition test and single radial haemolysis. No gross discrepancies were detected between the results of the two tests.

Comparison of proportions of children with rubella antibodies in 1985-6 and 1969 by age. Values expressed as number of children with antibody/number of children tested (and percentage)

\begin{tabular}{lccccccc}
\hline Age: & $\begin{array}{c}1-3 \\
\text { months }\end{array}$ & $\begin{array}{c}4-6 \\
\text { months }\end{array}$ & $\begin{array}{c}7-11 \\
\text { months }\end{array}$ & $\begin{array}{c}1-2 \\
\text { years }\end{array}$ & $\begin{array}{c}3-5 \\
\text { years }\end{array}$ & $\begin{array}{c}6-12 \\
\text { years }\end{array}$ & $\begin{array}{c}13-20 \\
\text { years }\end{array}$ \\
\hline $1985-6$ & $10 / 12(83)$ & $1 / 12(8)$ & $0 / 21$ & $3 / 54(6)$ & $6 / 38(16)$ & $64 / 84(76)$ & $18 / 24(75)$ \\
$1969^{\star}$ & $14 / 19(74)$ & $3 / 18(17)$ & $0 / 19$ & $4 / 47(9)$ & $10 / 41(24)$ & $32 / 40(80)$ & $42 / 51(82)$
\end{tabular}

^ Figures from Brown et al. ${ }^{2}$

The table shows the distribution of rubella antibodies in the different age groups. For comparison the distribution of antibodies shown by haemagglutination inhibition in a similar study performed in Leeds in 1969 is included. ${ }^{2}$ Further analysis of the results showed that though only one $(11 \%)$ of nine children aged 5 years had acquired antibody, seven $(64 \%)$ of 11 children aged 6 years were seropositive.
Comment

These findings show that passively acquired maternal antibody is usually lost by the age of 7 months and that it is rare to acquire active immunity under 2 years of age. Even in the group of children aged 3-5 years only $16 \%$ had evidence of having had rubella, and most children acquired antibody between 6 and 12 years of age. This pattern is similar to that found in 1969 and shows no evidence of having been influenced by the rubella vaccination programme. This is not surprising as the policy adopted in the United Kingdom in 1970 was a selective one aimed at protecting girls before childbearing age and not at interrupting transmission of the virus. Although it has resulted in a decreased proportion of susceptible women of childbearing age, a considerable number remain at risk of contracting rubella in pregnancy. ${ }^{34}$ To protect them it has been proposed that the present vaccination programme be augmented by immunising boys and girls in early childhood. ${ }^{5}$ Our findings indicate that if a high rate of uptake was achieved it would have a large impact on reducing the pool of infection and hence on preventing congenital rubella.

It is difficult to interpret the finding of rubella antibody in a child who presents with sensorineural deafness in the second or third year of life. The knowledge that only $4 \%$ of children in Leeds have acquired antibody by the age of 3 should help to clarify this difficulty.

We thank our consultant colleagues for allowing us to include their patients in the study.

1 Pattison JR, ed. Laboratory investigation of rubella. London: HMSO, 1982. (Public Health Laboratory Service Monograph Series No 16.)

2 Brown T, Hambling MH, Ansari BM. Rubella-neutralising and haemagglutinin-inhibiting antibodies in children of different ages. BrMed $\mathcal{F} 1969$;iv:263-5.

3 Hambling MH. Changes in the distribution of rubella antibodies in women of childbearing age during the first eight years of a rubella vaccination programme. F Infect 1980;2:341-6.

4 Wild NJ, Sheppard S, Smithells RW. The consequences of antenatal rubella testing. Health Trends 1986;18:9-10.

5 Miller CL, Miller E. Rubella vaccination in the UK: time for a complete strategy. Lancet 1985;ii:732

(Accepted 6 October 1986)

Department of Paediatrics and Child Health, Leeds General Infirmary, Leeds LS2 9NS

N D MUNRO, MRCP, tutor

N J WILD, MRCP, lecturer

$S$ SHEPPARD, MB, CHB, senior research fellow

R W SMITHELLS, MD, FRCP, professor of paediatrics

Department of Virology, Public Health Laboratory, Leeds LS15 7TR

M H HAMBLING, MD, FRCPATH, consultant virologist

Correspondence to: Dr Munro.

\section{Eye injuries caused by directed jets of water from a fire hose}

We report two cases of eye injuries caused by jets of water from a fire hose. Palpebral laceration and rupture of the orbital septum caused by sprinkler jets used in agricultural irrigation have been described, ${ }^{1}$ but to our knowledge severe intraocular injuries have not been reported.

\section{Case reports}

Two students were hit in the face by a jet of water from a fire hose at close range during their university's "rag week." The pump pressure was $10 \mathrm{bars}\left(150 \mathrm{lb} / \mathrm{in}^{2}\right)$, the diameter of the hose $45 \mathrm{~mm}$, and the diameter of the hose nozzle $20 \mathrm{~mm}$. The length of the hose was $75 \mathrm{~m}$, and the jet was directed from less than $5 \mathrm{~m}$.

\section{CASE 1}

A student presented to the eye department immediately after the accident with reduced vision in both eyes. The visual acuity was $6 / 36$ in the right eye, and there was perception of light in the left. Extensive lid ecchymosis and subconjunctival haemorrhages suggested bilateral retrobulbar haemorrhage. Extraocular movements were full, and there was no proptosis. Pupillary reactions to light and accommodation were reduced in both eyes. Slit lamp examination of the left eye showed a $2 \mathrm{~mm}$ hyphaema; the pupil was dilated and the iris sphincter ruptured. The right eye showed dispersed blood in the anterior chamber with an oval pupil. The intraocular pressure in the left eye was raised at $28 \mathrm{~mm} \mathrm{Hg}$ and in the right eye was normal at $18 \mathrm{~mm} \mathrm{Hg}$.

The patient was admitted to hospital for bed rest and was treated with 